\title{
Engineering Management and Industrial Engineering: Six One Way, A Half Dozen the Other
}

\author{
Susan L. Murray Ph.D., P.E. \& Stephen A. Raper Ph.D. \\ Engineering Management Department \\ University of Missouri-Rolla \\ Rolla, Missouri 65409-0370, USA
}

\section{Introduction}

To some people Engineering Management (EMgt) is a speciality within Industrial Engineering (IE), to others Engineering Management is broader than IE. For some the terms are interchangeable. Is there a difference? In this paper we present a comparison of the two disciplines to show there are similarities and differences.

\section{History}

Comparing the histories of the two disciplines shows a clear distinction. IE is a significantly older program. The first Industrial Engineering degree program was established in 1908 at Penn State. The much younger Engineering Management discipline began with the University of Missouri-Rolla program in 1967. ${ }^{(10)}$ However, other sources note MIT began a program similar to Engineering Management in about 1915. ${ }^{(11,12)}$ The first Industrial Engineering Ph.D. awarded in the United States went to Ralph M. Barnes from Cornell University in 1932. His thesis lead to the publication of the "Motion and Time Study" textbook. ${ }^{(7)}$ The University of Missouri-Rolla awarded the first Engineering Management doctorate of philosophy in 1984 to Madison Daily. (He is currently an active member of ASEE.)

Both disciplines have their roots in the work of engineering pioneers at the turn of the century. Work in motion and time study, along with other efficiency driven techniques, was the beginning of Industrial Engineering. One of the most famous of these pioneers was Frederick Taylor. His efforts to quantify work effort resulted in Taylor being considered, by many, the father of scientific management. Other early pioneers include Henry Gantt, Harrington Emerson, and Frank and Lillian Gilbreth. Both IE and EMgt can trace their roots to the era of scientific management and the work of these individuals. A noted change for Industrial Engineering occurred after World War II when many programs shifted their focus towards Operations Research. ${ }^{(13)}$ For some this shift marks the beginning of the distinction between the two disciplines. 


\section{Definitions}

Engineers have attempted to define both fields, but no one definition is agreed on by everyone. The definitions are often very similar.

Engineering Management is designing, operating and continuously improving purposeful systems of people, machines, money, time, information and energy by integrating engineering and management knowledge, techniques and skills to achieve desired goals in a technological enterprise through concern for the environment, quality and ethics. ${ }^{(5)}$

A second definition states Engineering Management is the discipline addressed to making and implementing decisions for strategic and operational leadership in current and emerging technologies and their impacts on interrelated systems. ${ }^{(12)}$

In 1989, IIE prepared the following definition of IE to reflect what the profession would be in 2000:

Industrial Engineering will be recognized as the leading profession whose practitioners plan, design, implement, and manage integrated production and service delivery systems that assure performance, reliability, maintainability, schedule adherence and cost control. These systems may be sociotechnical in nature, and will integrate people, information, material equipment, processes, and energy throughout the life cycle of the product, service, or program.

The profession will adopt as its goal profitability, effectiveness, efficiency, adaptability, responsiveness, quality, and the continuous improvement of products and services throughout their life cycles. The humanities and social sciences (including economics), computer sciences, basic sciences, management sciences, highly developed communications skills along with physical, behavioral, mathematical, statistical, organizational, and ethical concepts will be used to achieve these ends. ${ }^{(14)}$

It is readily apparent that no clear distinctions can be made between the two definitions. Both are concerned with operating and improving complex systems. Both fields are very broad and challenging to define!

\section{Academic Programs}

A numerical comparison of the Engineering Management and Industrial Engineering programs in the United States is presented in Table 1. Reviewing the data, it becomes apparent that IE has more programs and more graduates. The starting salaries for all practical purposes can be considered equivalent. (Note: The salary data is from two different sources; direct comparisons may not be valid.) 
Table 1. U.S. PROGRAMS COMPARISON

\begin{tabular}{|l|l|l|}
\hline & Engineering Management & \multicolumn{1}{|c|}{ Industrial Engineering } \\
\hline $\begin{array}{l}\text { Number of Undergraduate } \\
\text { Programs }\end{array}$ & $25^{(1)} *$ & $102^{(2)}$ \\
\hline $\begin{array}{l}\text { Number of ABET } \\
\text { Undergraduate Accredited } \\
\text { Programs }\end{array}$ & $3^{(3)}$ & $95^{(2)}$ \\
\hline $\begin{array}{l}\text { Number of Graduate } \\
\text { Programs }\end{array}$ & $20^{(4)} *$ & $79^{(4)}$ \\
\hline First Degree Program & $1967^{(5)}$ & $1908^{(6)}$ \\
\hline First Doctorate of Philosophy & $1984^{(5)}$ & $1932^{(7)}$ \\
\hline Average Starting Salary & $\$ 33,804^{(8)}$ & $\$ 36,281^{(9)}$ \\
\hline $\begin{array}{l}\text { Number of Full-time } \\
\text { Equivalent Faculty }\end{array}$ & $103.5^{(2)}$ & $1150^{(2)}$ \\
\hline $\begin{array}{l}\text { Number of Undergraduate } \\
\text { Degrees Awarded }\end{array}$ & $158^{(2)}$ & $3332^{(2)}$ \\
\hline
\end{tabular}

* These values listed differ significantly from those in the 1990 IEEE Transactions of Engineering Management editorial. ${ }^{(12)}$ The editorial denoted number of undergraduate programs equal to 29 and the number of graduate programs equal to 76 .

As can be seem from Table 1, IE programs are more numerous as both the undergraduate and graduate levels. However, if a broader interpretation of Engineering Management is allowed one source indicates that in 1990, there were at least 121 Engineering Management type programs at the graduate and undergraduate level. ${ }^{(12)}$

\section{Curriculum}

The college classes that are included in the two fields are difficult to compare. Five programs were selected in both fields, IE (GA Tech, Penn State, Purdue, Texas A\&M, and Virginia Tech) and EMgt (Steven's Institute, Univ of Tenn - Chattanooga, U.S. Military Academy, Univ Missouri-Rolla, Univ of the Pacific). Some core engineering courses were common to both groups. These included: calculus, chemistry, circuits, engineering economy, physics, and statistics/dynamics. There are also common humanities and English requirements. 
Table 2. CURRICULUM DISTINCTIONS

\begin{tabular}{|l|l|}
\hline \multicolumn{1}{|c|}{ Engineering Management } & \multicolumn{1}{c|}{ Industrial Engineering } \\
\hline Accounting & Facility Design/Layout \\
\hline Finance & Human Factors \\
\hline Marketing & Integrated Systems \\
\hline $\begin{array}{l}\text { Organizational Behavior (General } \\
\text { Management) }\end{array}$ & Manufacturing \\
\hline Production/Operations Management & Operations Research \\
\hline Project Management & Quality Control \\
\hline
\end{tabular}

There are also common courses that are electives or preferences in many of the universities. These are shown in table 3.

Table 3. CURRICULUM OVERLAP

\begin{tabular}{|l|l|l|}
\hline Computer Integrated Mfg. & Cost Accounting & Facility Layout/Location \\
\hline Linear Programming & Logistics & Safety \\
\hline Scheduling & Statistical Quality Control & Technical Writing \\
\hline Total Quality Management & Work Measurement & \\
\hline
\end{tabular}

\section{Conclusions}

In many ways Industrial Engineering and Engineering Management are very similar. Industrial Engineers are faculty members in Engineering Management departments and vice versa. Numerous entry level positions in industry are often filled by graduates of both programs. The history and size of IE is definitely greater, although EMgt graduate programs are experiencing significant growth. The curriculum of both programs are fundamentally the same. The distinction is that the EMgt student is receiving more education in traditional business functions and the IE student is receiving more education in specialities such as operations research and/or human factors. Both fields have bright futures, preparing engineers to face the diverse challenges of the next century. 


\section{References}

1. ASEE, 1994 Directory of Engineering and Engineering Technology Undergraduate Programs, pp. 40-41, 1994.

2. ASEE, 1994 Directory of Engineering and Engineering Technology Undergraduate Programs, p. 398, 1994.

3. ASEE, 1994 Directory of Engineering and Engineering Technology Undergraduate Programs, p. 592, 1994.

4. ASEE, 1994-95 Directory of Engineering Graduate Studies and Research, p. 432-433, 1994.

5. ASEM Conference Proceeding, "Engineering Management at the University if Missouri-Rolla: A New Discipline in Engineering or Management?", Yildirim “Bill” Omurtag, University of Missouri-Rolla, pp. 35-39, 1988.

6. Emerson, Howard P., Naehring, Douglas C.E., Origins of Industrial Engineering, Industrial Engineering \& Management Press, 1988, p. 44.

7. Niebel, Benjamin W., Motion and Time Study, Ninth Edition, Irwin Publications, p. 25, 1993.

8. David Britton, Career Opportunity Center, University of Missouri-Rolla, Interview, February 20, 1997.

9. Salary Survey, September 1996, National Association of Colleges and Employers, Bethlehem, PA.

10. Sarchet, Bernard R., "Engineering Management - Key To The Future", Engineering Management Journal, Vol. 1, No. 1, March 1989, pp. 4 - 7.

11. Kocaoglu, Dundar F., "Strategic Opportunities For Engineering Management," Engineering Management Journal, Vol. 1, No. 1, March 1989, pp. 8 - 10.

12. Editorial, "Research and Educational Characteristics of the Engineering Management Discipline," IEEE Transactions On Engineering Management, Vol. 37, No. 3, August 1990, pp. 172 - 176.

13. Waters, Robert C., "Engineering Management Tradition And Education: Past, Present, and Future," Engineering Management Journal, Vol. 6, No. 3, September 1994, pp. 5 - 8.

14. Salvendy, Gavriel (editor), Handbook of Industrial Engineering, Second Edition, John Wiley and Sons, Inc., p. 4, 1992.

\section{SUSAN MURRAY}

Susan Murray is an Assistant Professor in the Engineering Management Department of the University of MissouriRolla. She received her B.S. and Ph.D. in Industrial Engineering from Texas A\&M University. Her M.S. is also in Industrial Engineering from the University of Texas-Arlington. Dr. Murray is a Registered Professional Engineer with over seven years of industrial experience. She serves as the ASEE newsletter editor for the Engineering Management Division.

\section{STEPHEN RAPER}

Steven Raper is an Assistant Professor in the Engineering Management Department of the University of MissouriRolla. He received his B.S., M.S., and Ph.D. in Engineering Management from the University of Missouri-Rolla. He has extensive expertise in Packaging Engineering. In addition, he has served as the ASEE Engineering Management Division Chair. 